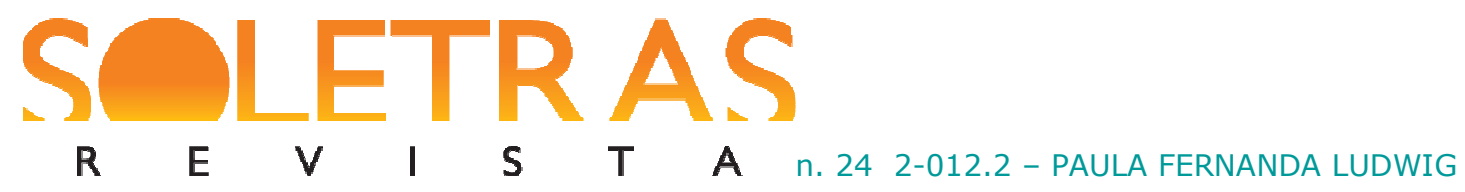

\title{
Leituras intersemióticas sobre dramaturgia: uma perspectiva a partir do melodrama
}

\author{
Paula Fernandes Ludwig ${ }^{1}$
}

Resumo: Este trabalho estuda um tipo de texto dramatúrgico denominado melodrama, visando entender sua constituição a partir de uma perspectiva intersemiótica que leva em consideração a tessitura do drama, tanto no âmbito literário quanto no âmbito cênico. Pretende-se partir do melodrama, apoiando-se na análise da peça A filha do mar (LUCOTTE, s/d) para abarcar reflexão mais abrangente, cujo alcance engloba a noção de dramaturgia como lugar do encontro entre sistemas semióticos diversos e ponto de convergência entre os códigos literário e cênico. Para tanto, leva-se em consideração um campo teórico que abrange, desde uma perspectiva acerca deste gênero até os pontos de vista da Estética da Recepção, culminando em uma reflexão que excede as estruturas literárias e visa atingir a noção de linguagem como um todo.

Palavras-chave: Teatro. Literatura. Relações intersemióticas. Melodrama.

Este trabalho apresenta o estudo de um tipo de texto dramatúrgico, referente à forma teatral melodrama, visando entender sua constituição a partir de uma perspectiva intersemiótica que leva em consideração a tessitura do drama, tanto no âmbito literário quanto no âmbito cênico. Apoiando-se na análise da peça $A$ filha do mar (de Lucotte) ${ }^{2}$, para tentar abarcar uma reflexão mais abrangente, cujo alcance englobe a noção da dramaturgia como o lugar do encontro entre sistemas semióticos diversos, busca-se estabelecer um ponto de convergência entre os códigos literário e cênico.

Ressalta-se que a investigação interdisciplinar permite a observação da assimilação criativa de elementos ao texto, favorecendo a compreensão dos processos de produção literária. Além disso, explorar um mesmo problema sob diferentes perspectivas permite a

\footnotetext{
1 Doutoranda em Estudos Literários, na linha de pesquisa Literatura, Comparatismo e Crítica Social, pela Universidade Federal de Santa Maria. Bacharel em Artes Cênicas e doutoranda em Estudos Literários pela Universidade Federal de Santa Maria. Bolsista CAPES.

${ }^{2}$ Essa peça faz parte de uma coleção de textos teatrais (manuscritos) referentes ao final do século XIX e início do XX, digitados pelo Grupo de Estudos e Pesquisa em Teatro Brasileiro (GETEB), da Universidade Federal de São João Del-Rei. Não há muitas referências sobre elas e, no caso do texto analisado, as informações disponíveis são de sua classificação como melodrama e a citação de "Lucotte" como autor. Em minha dissertação, intitulada Como se cria um vilão? Rumores e intrigas entre teatro e literatura - do melodrama à dramaturgia brasileira no século XIX (2012), disponível em www.ufsm.br/mletras, apresento um breve estudo sobre quem teria sido o dramaturgo em questão.
} 


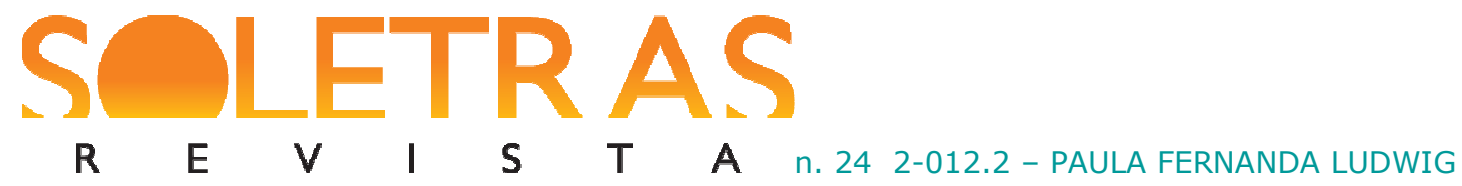

ampliação dos horizontes do conhecimento (CARVALHAL, 1986). Seguindo por esse caminho, em relação ao melodrama, destaca-se um ponto primordial: tentar entender como se constitui o processo de significação no tipo de dramaturgia vinculada a essa forma teatral.

Pensar sobre o teatro sob o ponto de vista da significação compreende discorrer acerca de uma obra artística, um constructo, que parte do mundo para nele se inserir novamente (movimento que não é impune nem inconsequente). Isso implica refletir acerca de uma ideia complexa, fonte para diversos debates teóricos, mas que não perde a força de sua recorrência. Trata-se de pensar a obra como representação.

Vários são os caminhos por onde andar quando nos dirigimos a esse assunto e, nesse caso, faz-se necessário um recorte. Primeiramente, delimita-se este trabalho ao encontro entre teatro e literatura e, ao abordar esse âmbito, destaca-se a obra cênica com um constructo ficcional cuja constituição dá conta de um processo de significação que se inicia com a dramaturgia e culmina no palco. $\mathrm{O}$ artigo buscar entender como uma obra ficcional se carrega de significados, implicando um procedimento que sugere a análise do processo de significação como fato que não acontece apenas por conta da obra em si, mas em função do vínculo que ela estabelece com a realidade em que se insere - ela vive à medida que o público a vive. Ao ganhar vida, ganha também significados, relacionando-se com o mundo, designando conhecimentos próprios da condição humana, associando-se a maneiras como o homem constrói, habita o mundo.

A perspectiva da obra ficcional como um constructo, como uma realidade construída pelo homem, abre espaço para a consideração de interações traçadas através de jogos de linguagens. A capacidade de percepção da realidade está associada à linguagem, a uma forma de compreensão e representação dos matizes do mundo. A obra artística é permeada pelo “encontro de uma consciência e do mundo" (GADAMER apud BESSIÈRE, 1995, p. 383) e o texto, decorrente desse encontro, mostra-se como uma forma de estruturar, constituir um real. O enunciado é veiculado por uma formalização da linguagem e os elementos dessa formalização geram significados.

A exploração de matizes do real e não de uma realidade absoluta, apesar da possibilidade de haver o intuito de criação desse efeito na obra, destaca na construção ficcional não a necessidade de verbalizar o que se realiza realmente, mas o que poderia realizar-se na ordem do verossímil. Não há o compromisso com uma verdade, mas com a 
$\begin{array}{lllllllll}\mathbf{R} & \mathbf{E} & \boldsymbol{V} & \mathbf{I} & \mathbf{S} & \mathbf{T} & \mathbf{A} & \text { n. } 24 & \text { 2-012.2- PAULA FERNANDA LUDWIG }\end{array}$

verossimilhança, com o convencimento. O objeto artístico assume-se como representação simbólica.

A representação pode ser vista como possibilidade de conhecimento e compreensão do mundo através de atos de manipulação de signos para a construção de sentidos. O trabalho não se dá com o elemento em si, mas sim com algo que toma o seu lugar - uma pedra esculpida pode representar um homem. Deve-se lembrar de que o uso do signo é individual, mas ele advém de e é emitido em um contexto social e histórico.

A afirmação citada acima dá conta de algo que funciona socialmente - pode-se argumentar que não existem objetos estéticos, mas sim o como olhar para um objeto e identificar nele uma função estética (MUKAROVSKÝ, 1977). O objeto pode ser construído visando à manifestação dessa propriedade, mas ela só se concretiza mediante uma percepção que se dá no contexto de sua recepção. A obra pode ter sido feita para suscitar efeitos, mas para que eles sejam concretizados e se mantenham, ela precisa ser socializada. Seguindo esse raciocínio, entende-se que a arte não se efetiva no material concreto, ela é uma ideia, passível de mudanças.

De acordo com tal pensamento, pode-se reivindicar a realização de um estudo acerca de determinado enunciado, como o texto escrito de uma peça (material que possibilitaria a realização de uma análise), de maneira a considerar uma perspectiva sobre o estudo do texto, cuja elaboração considere dois pontos em relação à obra: fatores internos e externos, o que se dirige para a consideração do vínculo entre obra e público, inserido num processo dinâmico de comunicação.

Tal proposta aproxima-se da chamada Estética da Recepção. Essa linha de pesquisa estabeleceu-se no âmbito de discussões teóricas, contrapondo-se, por exemplo, à crítica imanentista da época, cujo enfoque da obra literária ressaltava apenas o aspecto textual, desprezando elementos históricos e sociais. Nesse campo de posições divergentes, em que a problematização da relação entre arte e realidade era o ponto em comum, a Estética da Recepção afirmava-se com uma proposta de mudança de paradigma, evidenciando a preocupação com o público receptor nos estudos literários e, dessa forma, abrindo horizontes para a compreensão do texto, promulgando o entendimento de que o processo de significação não se esgota na escrita. 
$\begin{array}{lllllllll}\mathbf{R} & \mathbf{E} & \mathbf{V} & \mathbf{I} & \mathbf{S} & \mathbf{T} & \mathbf{A} & \text { n. } 24 & \text { 2-012.2-PAULA FERNANDA LUDWIG }\end{array}$

Wolfgang Iser, autor associado à Estética da Recepção, aborda a relação entre obra e seus efeitos, concretizados pelo receptor. Iser (2002) compreende o texto literário como um processo que engloba desde a reação do escritor perante um mundo até a experiência da leitura, postulando que é possível identificar no próprio texto as marcas de apelo ao seu público.

Esse caminho aproxima-se da reflexão acerca dos vínculos entre objeto artístico e mundo, representação e referente. O texto escrito, como construção verbal, linguística, é condicionado por um aparato finito. Já o seu referente, o mundo, é ilimitado. Como, então, relacionam-se esses dois vetores? Segundo Iser (2002, p. 105) "o texto ficcional é igual ao mundo à medida que projeta um mundo concorrente", a ficção "não possui os critérios de realidade, embora pareça simulá-los”, ela

[...] oferece caminhos de entrada para a realidade que finge, quando a julgamos do ponto de vista de sua função: ou seja, comunicar. Como estrutura de comunicação, não é idêntica nem com a realidade a que se refere, nem com o repertório de disposições de seu possível receptor (...) A não identidade da ficção com o mundo assim como da ficção com o receptor é a condição constitutiva de seu caráter de comunicação (2002, p. 105).

Nota-se que a obra, como estrutura de comunicação, não apreende o mundo em sua totalidade, mas interage com ele operando transgressões através de uma quantidade finita de determinações linguísticas. Mas, mesmo nesse processo, necessita de sua relação com o mundo:

[...] o sinal de ficção no texto assinalado é antes de tudo reconhecido através de convenções determinadas, historicamente variadas, de que autor e o público compartilham e que se manifestam nos sinais correspondentes. Assim, o sinal de ficção não designa nem mais a ficção, mas sim o 'contrato' entre autor e leitor, cuja regulamentação o texto comprova (ISER, 1963, p. 970).

A noção de contrato entre autor e leitor, "cuja regulamentação o texto comprova", aproxima a produção do texto escrito de sua recepção e assinala o próprio texto como fonte para a percepção de tal processo. Sob esse viés, o trabalho com o texto escrito a partir da problemática da representação, cuja perspectiva dilata-se entre material linguístico e campo 
$\begin{array}{lllllllll}\mathbf{R} & \mathbf{E} & \mathbf{V} & \mathbf{I} & \mathbf{S} & \mathbf{T} & \mathbf{A} & \text { n. } 24 & \text { 2-012.2-PAULA FERNANDA LUDWIG }\end{array}$

social, apresenta-se como fonte rica para realização de um estudo cujo enfoque se dirige para o texto no teatro.

Tal tarefa não é das mais simples, especialmente quando se percebe que o campo teatral é permeado por uma complexidade de estruturas formadas pelos signos do espetáculo, que envolvem elementos diversos, mesclam linguagens variadas. Nele, encontramos uma:

[...] série de signos de natureza visual, portadores de forma, cor, volume, luminosidade, e de signos sonoros, que poderão ir desde a palavra articulada até a música (...) desses signos, alguns se desenvolvem no espaço, outros no tempo; mas, há os que, como o movimento corporal, abrangem simultaneamente espaço e tempo (NUNES, 1977, p. XII).

Por esse caminho, sugere-se que lidar com o teatro é lidar com uma manifestação híbrida, fusão de diversas artes. No entanto, é possível pensar no teatro como "expressão única e independente, embora possa nutrir-se de elementos de outras linguagens" (IBIDEM, p. XIII), reconhecendo-se, assim, a especificidade da arte teatral e, dessa maneira, entendendo que a dramaturgia faz parte desse campo específico.

Se a dramaturgia está à mercê da especificidade que caracteriza a arte teatral e se, como postula Iser, é possível encontrar no próprio texto as marcas de sua recepção (momento essencial no processo de significação da obra), pode-se considerar pertinente a realização de uma análise acerca do texto dramatúrgico que destaque sua relação com o espetáculo teatral afinal, a dramaturgia visa à encenação. Essa perspectiva distancia-se de uma concepção exclusivamente literária do teatro, que o considera como veículo da literatura dramática “instrumento de divulgação a serviço do texto literário” (ROSENFELD, 1976, p. 19).

Tal ponto de vista, apoiado essencialmente em critérios literários, revela um posicionamento atrelado a uma determinada perspectiva histórica predominante na França, justamente na época do estabelecimento da forma teatral que embasará a análise a ser apresentada nesse trabalho - o melodrama. Tratava-se de um período em que a riqueza das obras dramatúrgicas vinculava-se a aspectos literários e a crítica aplaudia um tipo de teatro sustentado pelo império da palavra, como esclarecem Thomasseau (2005) e Camargo (2005). Nesse contexto, as peças melodramáticas, consideradas distantes dos padrões literários de excelência, eram alvo de críticas constantes e ferrenhas - prática que se estendeu ao longo dos anos, cristalizando-se pela repetição. 


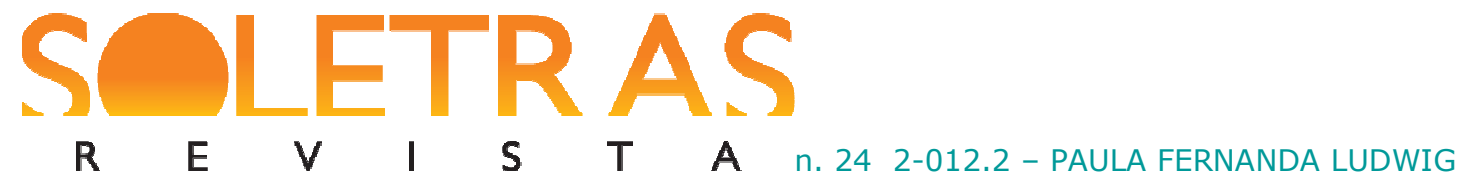

Sobre o melodrama, Thomasseau (2005) assinala-o como forma teatral de origem francesa, nascido no seio da Revolução Francesa, época de grandes transformações, com um contexto permeado pelo caos e por um cotidiano em que situações de violência frequentes acabavam por se tornar banalizadas. O melodrama foi capaz de se inserir nesse meio como fonte alimentadora de um povo massacrado por crises, fazendo com que, através do teatro, os mitos e o maravilhoso voltassem a fazer parte da vida das pessoas. Suas peças visavam contentar diferentes classes sociais, levando em conta uma certa missão educadora, baseada em princípios moralizantes, perante um público considerado, em sua grande maioria, analfabeto e inculto.

Eram inúmeros os recursos explorados pelas encenações na busca por sensibilizar e cativar o público. Dessa forma, as peças estavam direcionadas para o desenvolvimento cênico em sua completude e valorizavam desde questões técnicas, como cenário e figurino, até a interpretação dos atores, essencial para o drama.

Camargo (2005) sublinha que o melodrama utiliza de forma radical a produção complexa de seu espetáculo, cuja composição apóia-se em diversos recursos, como o uso de maquinário, efeitos cênicos e o desenvolvimento da gestualidade e presença do ator em cena. Tal relação com a realização cênica manifesta-se no texto das peças através do uso constante de rubricas.

Funções como comentário, acentuação e descrição, tradicionalmente desempenhadas pelo narrador, em textos narrativos (que visam atingir o público leitor), no caso de uma peça teatral, geralmente não são enfatizadas no diálogo escrito, em que se destaca a ação apresentada como tal, e vão se efetivar na cena, através da exploração de elementos como a cenografia, a pantomima e a música. Contudo, há um espaço característico para semelhante papel no texto dramático: as rubricas - "Essa função se manifesta no texto dramático através das rubricas, rudimento narrativo que é inteiramente absorvido pelo palco" (ROSENFELD, 2008, p. 35).

As rubricas são registros escritos, cuja real efetividade e sentido estão na prática, na encenação. Sua presença na dramaturgia, segundo Ramos (1999, p. 15): “compreende a literatura dramática como necessariamente vinculada a um fazer teatral específico e não como autônoma do espetáculo". Trata-se de um espaço direcionado à montagem, "registro literário de uma certa poética cênica, o vestígio ou a marca de um método" (RAMOS, 1999, p. 17). 


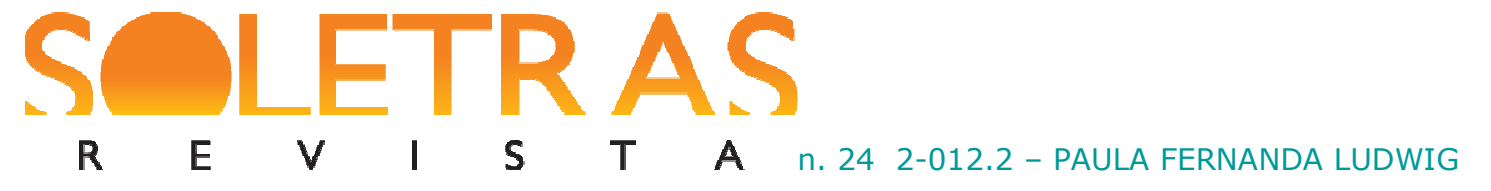

Segundo Camargo, as rubricas aparecem constantemente na tessitura das peças melodramáticas e essa observação leva ao apontamento de seus textos como textos espetaculares (DE MARINIS apud CAMARGO, 2005), isto é, textos escritos visando exclusivamente à encenação. As obras não são elaboradas para serem apreciadas como objeto literário, mas com o intuito primordial de favorecer sua construção cênica.

Pensar a dramaturgia melodramática como texto espetacular é reconhecer a ênfase de uma preocupação na escrita com a recepção que acontecerá no espetáculo, apontando para o reconhecimento da arte teatral como dependente de um fazer, do acontecimento no tempo e no espaço, no aqui e agora - fruto de ocorrências singulares (os espetáculos não se repetem

simplesmente, mas geram novos acontecimentos a cada nova encenação), para a concretização do seu processo de significação. Essa perspectiva tende a acentuar, no texto escrito, através das rubricas, elementos que extrapolam os limites do papel. Mais ainda: se o melodrama é radical na exploração de seu potencial espetacular, cogita-se o quanto sua tessitura escrita ganha significativamente com a indicação de possibilidades cênicas.

Para tentar elucidar tal questão, segue uma breve análise baseada no melodrama A filha do mar, com o intuito de buscar, no texto escrito, como se constitui essa preocupação com a recepção do público e com o processo de significação motivado por tal conduta. Essa peça, constituída de um prólogo e quatro atos, conta a história de uma menina órfã, resgatada de um naufrágio. Ela cresce em meio a pessoas simples e, já moça, trabalha como dama de companhia na casa de aristocratas. Lá, apaixona-se pelo Conde, contudo, a diferença de classe social impossibilita o amor entre os dois. Para complicar a situação, a trajetória da protagonista fica à mercê das peripécias do mordomo da casa, identificado como o vilão da história, cuja ação desencadeia diversos acontecimentos que atormentam a pobre mocinha. No entanto, já pelo fim do drama, descobre-se que a órfã é na verdade a filha desaparecida da Condessa. O vilão é desmascarado e preso. Sendo a menina nobre, pode casar-se com o seu amado.

Esse é basicamente o enredo da peça. Simples, previsível, baseado na ação de personagens estereotipadas - características que, não raro, fundamentam críticas negativas. No entanto, ressalta-se que o estudo apresentado nesse trabalho pretende sublinhar uma perspectiva diferenciada acerca da dramaturgia melodramática, cujo foco de análise não esteja delimitado por categorias básicas de conteúdo, temática e organização de enredo, 
$\begin{array}{lllllllll}\mathbf{R} & \mathbf{E} & \mathbf{V} & \mathbf{I} & \mathbf{S} & \mathbf{T} & \mathbf{A} & \text { n. } 24 & \text { 2-012.2- PAULA FERNANDA LUDWIG }\end{array}$

correspondentes a um ponto de vista exclusivamente literário. Busca-se antes, extrapolar o texto escrito a partir da constatação da ênfase de seu vínculo com a realização espetacular e com a compreensão das inúmeras possibilidades de significação que tal postura pode gerar, especialmente ao reconhecermos que esse procedimento vincula-se diretamente à consideração do momento da recepção da obra pelo público.

As rubricas indicam a composição de uma escrita direcionada para a encenação das situações contidas no texto dramático. No caso da peça $A$ filha do mar, percebe-se, nas situações, uma tentativa de aproximação com uma realidade empírica - os locais onde se passa a ação, a classe social de cada personagem, as profissões, títulos de nobreza... Nada disso foge à reprodução de noções conhecidas no mundo empírico. Nota-se o uso desse tipo de referente que se estabelece por si - não há a exploração de uma projeção do mundo a partir de uma de uma percepção subjetiva da realidade e de suas coordenadas, o espaço e o tempo (em que a consciência prescreve as leis do mundo e não o contrário). A percepção subjetiva é característica de representações abstratas em que se busca eliminar a ilusão de espaço e tempo como elementos bem organizados. Contudo, não é essa a organização verificada na peça de Lucotte em que tempo e espaço são definidos segundo uma organização lógica, causal.

$\mathrm{O}$ uso da sequência causal assinala uma maneira de perceber a realidade segundo uma ordem natural, não caótica. As situações obedecem a uma causa, podem ser explicadas, possuem lógica. Não há caos, busca-se a clareza da exposição. A preocupação com a clareza pode ser percebida constantemente na peça: apesar dos engodos e das reviravoltas, a organização da trama segue a ordem causal, usa-se constantes apartes para que não sejam obscuras as intenções das personagens (que participam de um jogo maniqueísta, sendo facilmente identificáveis) e o único mistério que não é revelado com rapidez diz respeito à grande reviravolta no percurso da protagonista (ao descobrir ser filha da Condessa).

Esse tipo de construção não favorece a exploração de sentidos ambivalentes. O texto dramático enfatiza o direcionamento para uma apresentação que explora a provocação de efeitos não através de jogos semânticos contidos nas falas, mas através da exploração sensorial, associada à encenação. Tal aspecto pode ser verificado pela utilização de canções e rubricas que descrevem efeitos de cena, como explosões, trovões... Esses elementos apontam para o trabalho com outros tipos de linguagens, calcadas na sensibilidade humana, em vias ligadas ao sonoro e ao visual. 


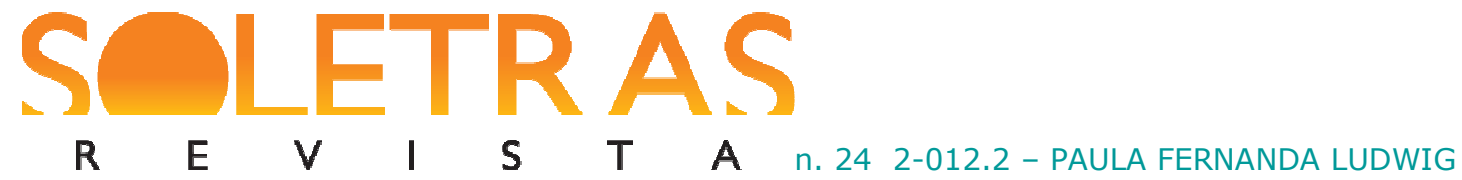

Além disso, observa-se que o texto dramático em questão não apresenta ênfase no disfarce das convenções cênicas pelo contrário, exploram-se recursos como a música e os efeitos que sinalizam para a grandiosidade e para o maravilhoso, o extraordinário, como o milagre da salvação com o aparecimento da aurora boreal, como pode ser constatado no seguinte trecho da peça:

CONDE: Então o que se deve fazer?

PEDRO: Esperar a morte!

TODOS: A morte!

LUIZA: A morte!... Resta-nos um recurso... Deus!

CONDE: De joelhos, todos, e peçam a Deus que lance sobre nós um olhar de compaixão! (Todos se ajoelham).

CORO: Virgem do céu e da terra,

Escutai-me esta oração,

Vinde pois, vinde, senhora!

Estender-me vossa mão!

LUIZA: Senhor, tende piedade de nós!... Aceitai a minha vida, mas salvai a destes desgraçados! (Ouve-se um tiro e principia a aparecer a aurora boreal).

VOZES (dentro): A Aurora!

TODOS: Aurora Boreal!

CONDE: Sim, a aurora boreal... Vede, meus amigos... é o farol grandioso que Deus acende nos pólos da terra para guiar os pobres navegantes!

(...)

TODOS: Está ao Norte!... Está ao Norte!... (todos manifestam grande alegria, a Aurora brilha com toda força. Cai o pano).

(LUCOTTE, s/d., p. 52).

A verificação da composição do texto dramático com o intuito enfatizado de encenação já aponta para esse aspecto. O teatro depende da convenção. A peça pode tentar recriar eventos que se assemelham a acontecimentos observados no mundo empírico, mas não pode fugir de suas condições - como elaborar uma aurora boreal sem o apoio do aparato técnico da iluminação? Como colocar um navio em cena, no palco? Como mostrar um batalhão do exército quando se dispõe de poucos atores? Nesse contexto, o simbólico é explorado em auxílio do vínculo que a obra pretende estabelecer com a plateia, especialmente, no caso da peça abordada, através da via da percepção sensorial e da emoção.

Apesar dos traços bem definidos, não se pode esquecer que a contingência pode até ser atenuada, mas jamais suprimida - aí está uma das grandes riquezas do objeto artístico, capaz de ultrapassar delimitações unilaterais e favorecer a exploração de inúmeras possibilidades. Assinala-se o caso da peça em questão: ela apresenta esquemas simplificados, de fácil 
identificação, sem níveis complexos de compreensão. Mesmo assim, a intenção, contida no texto, de exploração dos recursos próprios da representação cênica (que está diretamente relacionada com a presença viva do espectador) é capaz de enriquecer o arcabouço de possibilidades da obra.

Xavier (2003) esclarece que o melodrama supõe conflitos sem nuances entre bem e mal, oferecendo uma imagem simples de valores. Com isso, oferece matrizes aparentemente sólidas de avaliação das experiências num mundo tremendamente instável, o mundo moderno, marcado por mudanças que envolviam a economia, o poder político, sem autoridades absolutas, e a falta de rigor normativo no campo estético.

Ao oferecer essas matrizes, o melodrama é capaz de formalizar um imaginário que busca dar corpo à moral, torná-la visível e audível. Nesse processo, ele "provê a sociedade de uma pedagogia do certo e do errado que não exige uma explicação racional do mundo, confiando na intuição e nos sentimentos 'naturais’ do indivíduo” (XAVIER, 2003, p. 91).

Para estabelecer esses padrões, muito mais do que o texto escrito, o melodrama usa o texto de seu espetáculo, estimulando uma legibilidade que se dá por uma combinação visual e sonora - meio capaz de despertar a via do afetivo, afetando o espectador e conquistando sua credulidade pela via da emoção:

Vale na imaginação melodramática a ideia da expressão direta dos sentimentos na superfície do corpo, seja pelo gesto ou fisionomia que sublinha uma reação ou uma intenção da personagem (...) Tudo aí se traduz em imagem - o vilão é antes de tudo nos bigodes e na postura insinuante (XAVIER, 2003, p. 94).

A clareza na performance das personagens é essencial (as rubricas não promovem divergências, antes acentuam essa perceptibilidade): ao dizer tudo, fixam nitidamente um esquema moral do mundo, com modelos claros. A ênfase nos gestos e expressões (indicadas nos textos pelas rubricas) acentua a visibilidade da cena e a condição das personagens ganha corpo, torna-se real, pela performance cênica. Percebe-se o valor da exibição para a concretização da ficção perante o público.

Nota-se como a vinculação do texto escrito com o espetáculo cênico pode enriquecer a dramaturgia. A riqueza do texto pode não se concretizar em relação à qualidade literária, como é o caso do melodrama, contudo, a noção de texto espetacular amplia a percepção 


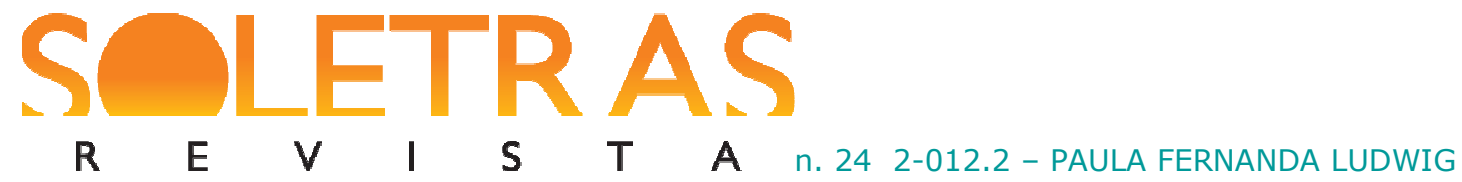

acerca desse tipo de dramaturgia, apontando a riqueza de sua composição relacionada a outros aspectos, como as possibilidades semânticas que podem surgir a partir da relação entre o âmbito da escrita e o âmbito da cena, entre dramaturgia e espetáculo, literatura e teatro.

O uso de outras linguagens no teatro, como a música, é uma estratégia recorrente para a efetivação de uma proposta espetacular. O texto escrito, a dramaturgia, faz parte desse universo, mas no caso do texto espetacular, ela se mostra como mais um elemento que compõe o conjunto da obra, cuja totalidade engloba desde o texto até o trabalho dos atores em cena.

A arte teatral é caracterizada pela exploração de várias linguagens em sua composição, efetivando-se tanto pelas vias do sonoro como pelas vias do visual. Quando a dramaturgia que a sustenta é vista como texto espetacular, entende-se que o seu texto escrito está vinculado às circunstâncias de enunciação e de fruição do espetáculo cênico, fator que enriquece seu arcabouço literário ao abrir campos de possibilidades significativas através da relação entre literatura e teatro.

Perceber esse movimento implica notar que, muito além da análise de um texto em específico, ao observar na dramaturgia o encontro/confronto - capaz de gerar uma terceira instância cuja avaliação não considera uma linguagem literária ou teatral, mas antes prevê códigos complementares que caminham em traço uno - reflete-se não apenas acerca da relação entre sistemas semióticos, mas também se pensa as possibilidades desse raciocínio para a concepção da própria linguagem.

Por esse rumo, pode-se verificar a ideia de sujeição a um jogo (há a vontade e o aceite em jogá-lo), repleto de convenções pré-determinadas, pelas quais se realizam movimentos indeterminados. Joga-se o jogo, mas ele não é absoluto, ele permite, até incita, o deslize, que, em meio a constructos humanos e incompletos, mostra-se recorrente, apontando a "não transparência da língua (gem)", a queda do pressuposto de um sentido sempre já lá.

Rancière (1995, p. 10) cita "a doença da escrita" contra a qual "tem pouco poder a disciplina que gostaria de atribuir a cada palavra a coisa exata que ela representa ou a ideia de que ela é o signo". A escrita vem da mão de alguém, há um ser humano, que faz parte de uma comunidade, histórica, guiando a tinta pelo papel:

Escrever é o ato que, aparentemente, não pode ser realizado sem significar, ao mesmo tempo, aquilo que realiza: uma relação da mão que traça linhas ou 


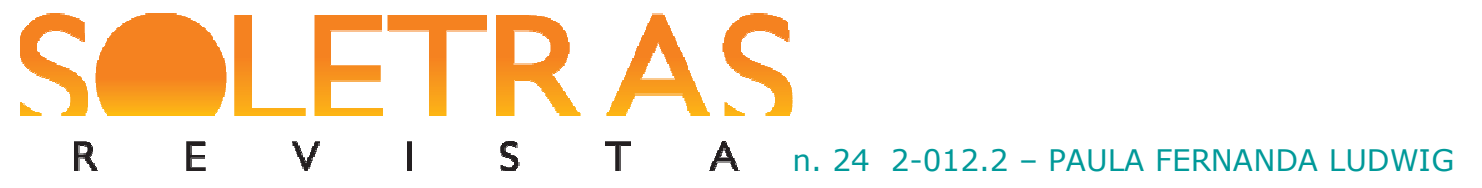

signos com o corpo que ela prolonga; desse corpo com a alma que o anima e com os outros corpos com os quais ele forma uma comunidade (...) antes de ser o exercício de uma competência, o ato de escrever é uma maneira de ocupar o sensível e de dar sentido a essa ocupação (...) é coisa de política porque seu gesto pertence à constituição estética da comunidade (...) Pelo termo de constituição estética deve-se entender aqui a partilha do sensível que dá forma à comunidade (RANCIÉRE, 1995, p. 7).

Mas é preciso lembrar que esse processo, em Rancière, também é marcado pela instabilidade - quando ele recorre ao mythos do Fedro em seu texto, expõe a problemática da escrita que é ao mesmo tempo "muda e falante demais" (RANCIÈRE, 1995, p. 8) - muda, pois "não há nenhuma voz presente para dar às palavras que ela arruma o tom da verdade delas", mas ao mesmo tempo, ela "está liberta do ato de palavra que dá a um logos sua legitimidade":

É por isso, também, que ela é falante demais: a letra morta vai rolar de um lado para o outro sem saber a quem se destina, a quem deve ou não falar. Qualquer um pode, então, apoderar-se dela, dar a ela uma voz que não é mais "a dela", construir com ela uma outra cena de fala, determinando uma outra divisão do sensível. Há escrita quando palavras e frases são postas em disponibilidade, à disposição, quando a referência do enunciado e a identidade do enunciador caem na indeterminação ao mesmo tempo (RANCIÈRE, 1995, p. 8).

Tem-se aí então uma concepção dupla da escrita, permeada pelo entendimento de uma "voz viva" com uma "escrita morta" - "a escrita é, indissoluvelmente, duas coisas em uma: é o regime errante da letra órfã cuja legitimidade nenhum pai garante" (percebe-se a saída de uma crítica tradicional que levava em conta o psicologismo do autor, por exemplo), "mas também é a própria textura da lei, a inscrição imutável do que a comunidade tem em comum" (RANCIÈRE, 1995, p. 9).

Percebe-se que há noção de que partilhamos um código, um sistema (potenciais virtuais) do qual nos apossamos para construir nossos enunciados, mas à medida que os colocamos no mundo, já não somos mais seus donos e não podemos garantir a transparência do sentido que queremos provocar (queremos dizer, mas ao fazer dizer, não necessariamente atingimos nossa intenção original) e na escrita, lugar que perde o momento e o tom emprestado pela oralidade, tal característica acentua-se. Contudo, pode haver escritas que trabalhem justamente com a intenção de apresentações imediatas do sentido no sensível e aí 
$\begin{array}{lllllllll}\mathbf{R} & \mathbf{E} & \boldsymbol{V} & \mathbf{I} & \mathbf{S} & \mathbf{T} & \mathbf{A} & \text { n. } 24 & \text { 2-012.2- PAULA FERNANDA LUDWIG }\end{array}$

poderíamos encaixar a constituição da significação no melodrama - ele se preocupa incessantemente com a clareza do que está sendo dito, não apenas na manipulação do entendimento das falas e da história, mas se nota uma busca por uma recepção sem falhas na constituição dos sentidos, fato acentuado pela exploração de conteúdos simples e personagens estereotipadas (trabalha com o senso comum), mas também pela ênfase no despertar da emoção, por via do sonoro e visual - pensa-se na exploração de efeitos, de gestos, cenários... aspectos próprios da encenação para reiterar os efeitos do drama - não há a constituição de um processo de significação cujo apoio principal esteja na exploração da relação entre o sentido e o $\operatorname{logos}$, há antes a significação que pretende se instaurar pela provocação da emoção, da sensação, por vias ligadas à sensibilidade sonora e visual, explorando efeitos que surgem pelo acontecimento cênico - que implica não só a partilha da língua, ela passa a ser sublinhada por outras camadas de linguagem, como a expressão corporal e a música.

Percebe-se que, por mais que procure a transparência de sentido, o melodrama demonstra a consideração de que, para atingir tal alvo, o apoio na língua somente não é o bastante. E mais: é preciso também extrapolar a noção de constituição da significação através apenas de um entendimento puro, racional - leva-se em consideração (e tal aspecto é enfatizado e explorado na escrita do drama) que a constituição dos sentidos está diretamente vinculada ao acontecimento da enunciação, à concretização de seu funcionamento, efetuada por seres que, ao se comunicarem, trabalham não apenas com construções lógicas - é preciso certa ordem para suscitar determinado entendimento, mas também com demais possibilidades que o sensível nos apresenta. A língua (gem) reconhece-nos como humanos.

\section{Referências bibliográficas:}

BESSIÈRE, Jean. Literatura e representação. In: ANGENOT, Marc (Org.). Teoria Literária. Lisboa: Dom Quixote, 1995.

CAMARGO, Robson Corrêa de. O espetáculo do melodrama: arquétipos e paradigmas. Tese (Doutorado em Teatro), ECA: USP, 2005.

CARVALHAL, Tânia Franco. Literatura comparada. São Paulo: Ática, 1986.

ISER, Wolfgang. Os atos de fingir ou o que é fictício no texto ficcional. In: COSTA LIMA, Luiz. Teoria da literatura em suas fontes. Rio de Janeiro: Francisco Alves, 1963. 
$\begin{array}{lllllllll}\mathbf{R} & \mathbf{E} & \mathbf{V} & \mathbf{I} & \mathbf{S} & \mathbf{T} & \mathbf{A} & \text { n. } 24 & \text { 2-012.2-PAULA FERNANDA LUDWIG }\end{array}$

A interação do texto com o leitor. In: COSTA LIMA, Luiz (Org.). A literatura e o leitor: textos de Estética da Recepção. São Paulo: Paz e Terra, 2002.

LUCOTTE. A filha do mar. Manuscrito digitalizado pelo Grupo de Estudos e Pesquisa em Teatro Brasileiro (GETEB), UFSJ, s/d.

NUNES, Luiz Arthur (Org.). O signo teatral: a semiologia aplicada à arte dramática. Porto Alegre: Globo, 1977.

RAMOS, Luiz Fernando. O parto de Godot e outras encenações imaginárias. São Paulo: Hucitec, 1999.

RANCIERÉ, Jacques. Políticas da escrita. Rio de Janeiro: Ed. 34, 1995.

ROSENFELD, Anatol. Texto, contexto. São Paulo: Perspectiva, 1976. O teatro épico. São Paulo: Perspectiva, 2008.

THOMASSEAU, Jean-Marie. O melodrama. São Paulo: Perspectiva, 2005.

XAVIER, Ismail. O olhar e a cena: melodrama, Hollywood, Cinema Novo, Nélson Rodrigues. São Paulo: Cosac Naify, 2003.

\title{
Intersemiotics readings about dramaturgy: a perspective from to melodrama
}

\begin{abstract}
This work presents the study about a type of dramaturgic text, a melodrama, aiming at understanding its constitution from an intersemiotic perspective that considers the fabric of the drama, both in the literary field and scenic field. Taking as point of departure the analysis of the melodrama A filha do mar (by Lucotte), trying to reflect about the dramaturgy as the place where several semiotics systems meet, point of convergence between literary and theatrical codes. For this, use theories about the melodrama and Reader Response Theory, culminating with a reflection about language.
\end{abstract}

Key words: Theater. Literature. Intersemiotic relantionship. Melodrama.

Recebido em: 16 de dezembro de 2012.

Aprovado em: 06 de janeiro de 2013. 